\title{
State of the Nation Address by President of the Republic of Kazakhstan Kassym-Jomart Tokayev
}

(September 1, 2021)

Послание Президента Республики Казахстан

Касым-Жомарта Токаева к народу

(1 сентября 2021 г.)

\section{UNITY OF THE PEOPLE AND SYSTEMIC REFORMS ARE A SOLID FOUNDATION FOR THE NATION'S PROSPERITY}

\section{Dear compatriots!}

Distinguished Members of Parliament and Members of the Government!

This year we are marking the 30th anniversary of our Independence - this is our most cherished treasure.

Thanks to the forward-looking policy of the First President, Kazakhstan has had notable success and became known all over the world.

In unity and harmony, we were able to build a new state: this is our greatest accomplishment.

We have strengthened the spirit of the nation by laying a solid foundation for development. We have become an influential member of the global community. Thanks to the stability in our society, we have embarked on the path of sustainable progress.

Together we are building a strong state. Sovereignty is not just an empty slogan and a loud word. It is important for us that every citizen should feel the fruits of independence - a peaceful life, social harmony, increased well-being of the people, and the confidence of young people in their future. 
All our endeavours are aimed at this. Thanks to the unity and constructive labour of the people of Kazakhstan, we have successfully overcome all difficulties and trials.

Our country is on the verge of the fourth decade of independence. It is already clear that this period will not be easy. Therefore, we must be ready for any challenges and threats, to continuously improve and always move forward.

My current State of the Nation Address is dedicated to the following issues.

\section{ECONOMIC DEVELOPMENT IN THE POST-PANDEMIC PERIOD}

Kazakhstan's economy, the largest in Central Asia, is currently experiencing the effects of the pandemic. Nevertheless, despite the difficulties, we are consistently implementing our policies.

We adopted the National Development Plan 2025 and switched to a new system of state planning to determine the medium-term economic policy and systematise state initiatives. National projects will be approved.

The strategic goal is to ensure our leading role in Central Asia and strengthen our position in the global economy.

A new instrument - the Strategic Investment Agreement has been introduced to further attract direct investment.

Concrete actions have been taken to optimise the quasi-public sector. The merger of the Baiterek and KazAgro holdings has been completed. Portfolio companies have been cut by half, and their staff number by one and a half times. As a result, a new powerful development institution has been created.

The state provided large-scale and operational support to citizens and businesses during the pandemic.

The programme Economy of Simple Things has proven its effectiveness. As part of its implementation, more than 3,500 projects were launched, 70,000 jobs were created, goods and services were produced for 3.5 trillion tenge (over USD 8.2 billion).

Thanks to the Business Road Map programme, 66,000 projects received state support. This helped to create and maintain over 150,000 jobs. 
The initiative for the early use of pension savings had a serious economic, but above all social effect. This measure has helped over a million of our fellow citizens to improve their housing conditions or reduce the mortgage burden.

Overall, there is a positive trend in the economic development of our country. Nevertheless, we must be frank that the situation is still difficult.

Therefore, I have decided to extend the term of the Economy of Simple Things and Business Roadmap programmes until 2022. The total amount of funds allocated for their financing will be at least one trillion tenge (over USD 2.3 billion).

Largely due to the low public debt and the presence of significant reserves, Kazakhstan is relatively successful in overcoming the consequences of the pandemic. This is our substantial competitive advantage, and it is important not to lose it.

However, recently there has been a tendency to increase the budget deficit and transfers from the National Fund to cover expenditure obligations. To follow such an "easy" path will not be possible all the time. The stock of financial stability is far from unlimited. Obviously, measures are needed to increase budget revenues. But first and foremost, we need control over the volume and efficiency of government spending.

To recover the assets of the National Fund, the implementation of fiscal rules should be accelerated. The corresponding legislative amendments should be adopted by the end of this year.

Overall, the country needs a set of rules for managing public finances: public debt, budget policy, the National Fund. I ask the Government and the National Bank to prepare a Concept for Public Finance Management by the end of the year.

Along with this, it is necessary to continue work on diversifying the economy, expanding the range of goods produced and the geography of exports.

At the end of 2020, for the first time in 10 years of industrialization, the contribution of the manufacturing industry to the development of the economy exceeded the share of the mining industry. The medium-term goal is to increase manufacturing exports by 1.5 times by 2025 , to $\$ 24$ billion, and labour productivity by $30 \%$. 
The law on industrial policy that is being drafted should focus on the challenges facing the manufacturing sector. One of them is the problem of access to raw materials. It is necessary to introduce a simple rule - the price of raw materials for the domestic industry must be affordable, and the volume must be sufficient. By the end of the year, the Government must find the best solution to this important task.

At the same time, it should be kept in mind that the resource potential of our country is not fully disclosed, the geological knowledge remains at a low level.

Investors' access to quality geological information needs to be increased. To achieve this, an effective National Geological Service should be created on the basis of disparate subordinate organizations. This organization should not become a monopolist that decides to whom and how to give access to the subsoil. Its role is to provide comprehensive service support to investors.

The subsoil use industry needs a new impetus, especially in terms of geological exploration and integrated subsoil study. The reforms initiated under the Plan of the Nation should be brought to practical completion an open digital database of geological information should be created, and investors should have access to it.

Mineral resources are a national treasure. Decisions on access to them through behind-the-scenes discussions in the quiet of offices should be outlawed. The relevant authorities will provide control on this issue.

The excessive presence of the state in the economy seriously hinders its growth and competitiveness, leads to corruption and illegal lobbying. State-owned enterprises still dominate many sectors and enjoy monopoly privileges.

We have started to solve these problems. As such, the Concept of Public Administration provides for measures to reduce the quasi-public sector, increase its efficiency, transparency, and accountability. The Supreme Council for Reforms has approved a new privatization plan. Now strict control is needed.

But there are other questions as well. In particular, why do individual national companies and state-owned enterprises operate at a loss, while their top leadership are not responsible for this? The Government has to solve this problem. 
We also faced uncontrolled inflation growth. The National Bank and the Government turned out to be powerless in the face of inflation, referring to global trends. Excuses like these highlight the vulnerability of the national economy. Another question arises: what then is the role of our professional economists?

The main task of the National Bank and the Government is to return inflation to the $4-6 \%$ corridor.

As a result of the implementation of anti-crisis measures with a total volume of 6.3 trillion tenge (over USD 14.7 billion), an excess money supply appeared in the economy. But there are niches to which these funds do not flow. Second-tier banks do not invest in small projects, especially in rural areas.

Therefore, it is necessary to use the potential of microfinance organizations. They work in the field, they know the clients, their business, and their opportunities. The National Bank and the Financial Regulatory Agency should prepare a package of decisions on this issue.

Work to reduce the level of stressed assets is of great importance.

We decided that the state should not help bankers. In addition, frozen assets need to be returned to economic circulation, but exclusively on a market basis. This requires a legal framework. The Government, together with the Agency for Financial Regulation, should submit the legislation to Parliament by the end of the year.

Now regarding the non-monetary components of inflation. The main one is food prices.

Much has been said about the enormous agrarian potential of Kazakhstan. But in the field of the agro-industrial complex, a lot of problems have accumulated.

First of all, it is ineffective pricing and distribution of food products. Earlier I talked about the importance of creating a network of wholesale distribution centres. This task is underway.

It is important to provide access to them for small agricultural producers, including, possibly, personal subsidiary plots. Monopolization of this market is unacceptable.

It is also necessary to ensure uniform control over prices along the chain from producer to consumer. Several departments are now responsible for 
this work. After the next jump in prices, instead of a thoughtful analysis and taking effective measures, they begin to "point fingers at each other". It's time to put things in order in this regard. It is necessary to delimit areas of responsibility, define one body as the main one, and prescribe clear regulations for the interaction of other departments. The Government must make a decision on this issue within a month.

Secondly, unfavourable weather conditions exposed serious problems in livestock. We took prompt measures to stabilise the food supply situation. However, systemic action is still needed in this area.

It is necessary to expand the area of cultivation of fodder crops and strengthen control over the observance of crop rotation, to make wider use of the possibilities of space monitoring and remote sensing of lands. It is also important to improve the efficiency of pasture use.

Today, farmers do not have access to grazing areas as they belong to persons with well-known surnames, who have built impregnable fortresses around their possessions. Governors cannot solve this problem for various reasons, including personal dependence.

The Government, together with authorised bodies, needs to take decisive measures to remedy the situation. Particular attention should be paid to providing the private farmsteads of villagers with pasture lands. Their legal status and support tools must be prescribed in a separate Law "On Personal Subsidiary Farms". The Government needs to develop legislation as soon as possible.

The sphere of veterinary medicine also requires improvement, which needs a clear delineation of functions and powers between the center and the regions. The health and productivity of livestock depends on the effective work of veterinarians in the field. And this, in turn, directly affects the well-being of rural residents.

Expansion of exports of a significant part of agricultural products is impossible without a modern veterinary service. Therefore, consistent work is required in this area: digitalization of processes, automation of data collection and transmission, personnel training and salary increases. By the end of the year, the Government must take concrete measures to reform the veterinary system. 
Thirdly, there is inconsistency in our agricultural policy. Politics also changes with the change of ministers. In such conditions, it is difficult for farmers to plan work for the future. It is necessary to work out a single general position. In accordance with it, it is necessary to revise and stabilise the mechanisms of subsidies.

Over the past five years alone, more than 2 trillion tenge (USD 4.7 billion) has been allocated for subsidies. Unfortunately, more than half of the criminal cases in the agro-industrial complex are related to the theft of subsidies. This situation is unacceptable.

It is necessary to strengthen the regulatory framework, introduce a system of effective planning and monitoring. The procedure for issuing subsidies should be clear and transparent. Subsidies should be fully available to small and medium-sized farms.

It is necessary to study in detail the instruments for stimulating the technological re-equipment of agriculture. About $90 \%$ of the technologies used in the agro-industrial complex are completely outdated and in need of modernization.

The agricultural subsidy policy needs to be brought in line with the industrial policy of the state. I ask the Government and the Baiterek Holding to prepare a package of proposals on these issues.

In general, the main task of the agro-industrial complex is to fully provide the country with basic food products.

This year I signed a law that finally put an end to the sale and lease of agricultural land to foreigners and companies with foreign participation.

The Land Code has been amended to encourage domestic investors to invest in the development of rural areas. These changes make it possible to involve agricultural land in a full-fledged economic turnover.

I am sure that all these decisions will have a beneficial effect on our agro-industrial sector, which will become one of the key points of growth of the national economy.

Next issue. In the modern world, one of the main factors of competitiveness is extensive digitization.

The transfer of modern digital technologies, the introduction of elements of Industry 4.0 are extremely important for Kazakhstan. We must actively work with our strategic partners abroad. 
At the same time, it is important to nurture and strengthen the domestic IT sector. The country needs young, educated, motivated personnel. In line with the National Digitization Project, it is necessary to train at least 100,000 highly qualified IT specialists.

The export of services and goods of the digital industry should reach at least $\$ 500$ million by 2025 .

These and other challenges will require a complete digital reboot of the public sector. Here, the main and long-standing problem is the lack of effective integration of information systems of state bodies. This issue requires a radical, speedy solution.

First, a fundamentally new architecture of "digital government" has to be built. All IT initiatives of the public sector will be based exclusively on the new platform of the Kazakh state technical supervision. It will eliminate duplication, ineffective costs, and bureaucracy, $100 \%$ of public services will be available to citizens from smartphones.

Secondly, we are launching a Digital Transformation Centre, where all business processes of government agencies will be revised and converted into a digital format.

Thirdly, it is necessary to create a platform for interaction between national companies and the IT community. The digital needs and demands of the quasi-public sector should be met as much as possible by the efforts of domestic companies.

Fourth, it is necessary to gradually expand and update data transmission lines, linking them with international corridors. Modern data centres should be built that can serve neighbouring countries.

We must realise our enormous information and telecommunications potential. In the new digital age, it will have geopolitical significance. Kazakhstan should become a central digital hub in a broad part of the Eurasian region.

To solve this issue, it is necessary, of course, to strengthen the personnel plan. I ask the Prime Minister to give me his suggestions.

The situation in Afghanistan and the general growth of global tensions has put before us the task of rebooting the military-industrial sector and the Military Doctrine. 
Strengthening our defence capability and increasing the responsiveness to threats should also become priorities of national importance. We must prepare for external shocks and worst-case scenarios. Modelling of risks coming from the outside has become highly relevant. It is necessary to conduct stress tests, work out scenarios, on the basis of which the action plans of the state apparatus will be developed and adjusted.

\section{IMPROVING THE EFFICIENCY OF THE HEALTHCARE SYSTEM}

Our proverb says, "Health is our main wealth".

The coronavirus has become a serious challenge for the health care system. The pandemic that has gripped the world is not receding. Every day, thousands of our fellow citizens fall ill, many die.

Since the early days of the pandemic, we have taken immediate action to control the spread of the infection.

Kazakhstan is one of the few countries that has released its own vaccine against the virus. We have no doubts about the efficacy and safety of our QazVac vaccine, in which other countries are already showing interest.

We have a sufficient supply of vaccines; Kazakhs have the opportunity to choose while many nations do not have this privilege.

Mass vaccination continues in the country, but its opponents are still present in society. They not only refuse to be vaccinated, but also urge the population not to do so. Succumbing to their influence, many have become disoriented.

All these people should understand that they are responsible not only for themselves, but also for the lives of others. Therefore, people should not follow the lead of individuals campaigning against vaccination.

Humanity has experienced more than one epidemic. We must not forget that many dangerous diseases were stopped only after the advent of vaccines.

In the near future, new strains of coronavirus may appear in the world, experts predict other pandemics. We cannot simply wait out these processes. We have to learn to live and thrive in such conditions.

Therefore, it is now important to purchase booster vaccines, to speed up the purchase of vaccines registered by the World Health Organization. 
It is also necessary to prepare the entire health care system for the transition to regular vaccinations.

A National Biosafety Forecasting System of the country should be established. This measure is provided for in the relevant legislation. I ask Parliament to ensure its adoption by the end of the session.

Many laboratories for sanitary and epidemiological expertise do not meet international standards. As part of the "Healthy Nation" national project, it should be envisaged to equip at least 12 laboratories with high-tech equipment. This will increase the level of compliance of our laboratories with international standards up to $90 \%$.

The situation with diseases not related to coronavirus should not be allowed to worsen. In a pandemic, routine screenings and surgeries are postponed. Many children do not receive routine vaccinations. Of course, this state of affairs is unacceptable.

The medical field needs substantial funding. We are talking about infrastructure, personnel, drug supply.

The pharmaceutical industry requires special attention. The fight against the virus has shown that the industry has become an important factor in competitiveness and security. Therefore, it will be necessary to create a Centre for laboratory and technical testing of medical devices, accredited in accordance with all international standards.

Cooperation with global pharmaceutical corporations should be intensified. It is important to attract investors, to ensure the transfer of technologies and the latest developments. It is necessary to expand the volume and range of off-take contracts with domestic producers. The share of medicines and medical devices of domestic production must be increased from the existing 17 to $50 \%$ by 2025 .

The key to health is the culture of exercise. I reiterate, it is necessary to create all conditions for mass and children's sports. Governors of the regions should ensure the phased construction of the sports infrastructure.

Overall, in connection with the results of the Tokyo Olympics, there is a need to consider the state of affairs in sports at a separate meeting. 


\section{QUALITY EDUCATION}

Since January of this year, the salary of teachers has increased by $25 \%$. Over the next three years, we will additionally allocate 1.2 trillion tenge (over USD 2.8 billion) for these purposes. The measures taken are bearing fruit - the average score of applicants to pedagogical specialties has grown sharply.

We will continue our policy of supporting teachers. At the same time, in the context of global changes, it is highly likely that the knowledge acquired will become outdated before the graduate enters the labour market. Therefore, the relevant ministry faces the urgent task of adapting curricula to new realities.

The results of distance learning during a pandemic indicate the insufficient efficiency of national communication networks. This led to the emergence of a large number of students who do not possess basic, elementary knowledge. Another problem has arisen, one might say, trouble: children drop out of school because they do not see the need for it.

The Government is instructed to seriously address this issue, in particular to improve the quality of information systems for remote learning formats. Our education must be accessible and inclusive.

But there are some positive news as well. This year, several Kazakh schoolchildren became winners of international Olympiads.

Such talented children need to be fully supported. We will provide them with grants for admission to universities on a non-competition basis and pay one-time cash bonuses. Teachers who taught these children should also be encouraged morally and financially.

It is fundamentally important to support children from socially vulnerable families within the framework of "universal education". Material support measures should be supplemented with an educational project Digital Teacher.

The education system needs motivated and qualified teachers. I believe that retraining of teachers is required every three years, and not every five years, as it is now. After all, they should be the carriers of new knowledge, real enlighteners. At the same time, cases should not be allowed when teachers take courses at their own expense.

The shortage of places in schools remains an acute problem of the secondary education system and the deficit is 225,000 places. If urgent measures 
are not taken, then by 2025 it could reach one million places. Earlier, I gave instructions on the construction of at least 800 schools by the end of 2025 . Today I set the task to bring this figure to 1,000 schools.

In addition to construction at the expense of the budget, it is necessary to involve the private sector in solving this acute problem.

A phased transition to per capita financing and full-fledged rural schools should begin.

Early vocational guidance for children is of particular importance. The younger generation should be conscious of the choice of a future profession. The Government, together with the Atameken National Chamber, needs to tackle this important task.

We will continue to implement the Free Technical and Vocational Education project.

Today, 237,000 people from among the NEET (Not in Employment, Education, or Training) youth remain unreached. Every year 50,000 applicants enter on a paid basis, $85 \%$ of them are classified as low-income. This situation needs to be corrected. It is necessary to ensure 100 percent coverage of free TVE (Technical and vocational education) for in-demand specialties.

Another opportunity for obtaining a profession should be the army. It is necessary to work out the issue of the development by conscripts of job specialties necessary in the real sector of the economy.

The task of the relevant ministry is to ensure the improvement of the quality of higher education. Universities are obliged to be responsible for the proper training of personnel.

The most important priority is the development of science. To solve the accumulated problems in this area, it is necessary to amend the legislation by the end of the year.

First of all, it is necessary to ensure a stable and decent salary for leading scientists, including it in the basic funding of science. At a meeting of the National Council of Public Trust, I instructed to introduce direct funding for research institutes involved in fundamental science. The relevant ministry should develop clear and transparent rules for the selection and funding of such scientific organizations.

Furthermore. A serious barrier to the development of basic science is that grants are limited to three years. In such a short planning horizon, it is 
difficult to achieve any meaningful results. Consideration should be given to increasing the period of grant funding for science to five years.

The problem of the objectivity of the decisions of the National Scientific Councils is still on the agenda. I believe that a need has arisen to introduce the institution of appeal.

Ultimately, Kazakh education and science are faced with a large-scale, urgent task - not just to keep up with new trends, but to be one step ahead, to generate trends.

\section{IMPROVEMENT OF REGIONAL POLICIES}

The main principle of the "listening state" is that the state apparatus should work in the interests of citizens. This primarily concerns local authorities. It is the governors' offices that are called upon to interact with citizens and promptly solve their problems. However, this often does not happen. Central management occasionally has to correct decisions made in the regions or even make decisions for them.

Governors of different levels are not always capable of strong independent decisions; they look to the Centre. This is largely due to the fact that the current level of accountability of governors to citizens is insufficient. The assessment of their activities practically does not depend on the opinion of the residents of the regions themselves. Therefore, it is necessary to optimise the mechanism for evaluating the work of governors at all levels.

Independent opinion polls should be an important approach. They give an objective picture of the real attitude of the population to the quality of the work of the authorities. Citizens' voices are heard directly through polls, not through formal reports. The Presidential Administration should prepare a package of proposals on this issue.

In regional policy, primary attention should be focused on reducing imbalances in socio-economic development. It is necessary to correctly combine the tasks specific to each region with national priorities.

As part of the National Development Plan, 25 specific tasks were identified to improve the quality of life of citizens. These are the main directions of our work. Therefore, the Government and governors will have to update the Regional Development Plans in accordance with the approved national goals. 
Of course, one of the main tools for reducing imbalances is the prioritization of budget expenditures. The allocation of funds from the state budget should not depend on the "pushy power" of governors, any personal preferences, and other subjective factors.

To "reboot" the budgeting processes, it is necessary to use the per capita financing mechanism more widely; it is necessary to introduce an objective method of allocating budget limits.

It is necessary to simplify budget processes, radically reduce bureaucracy in this matter, and expand the use of digital tools for planning and budget execution. It is necessary to introduce a block budget with increased responsibility of administrators of budget programmes. The Government needs to develop a package of amendments to budget legislation and by-laws.

An extremely acute problem is the systematic overestimation of the cost of projects. This applies to both small facilities, such as kindergartens and schools, and large infrastructure projects. The current regulatory framework and practice should be radically revised as soon as possible. The Government, the Accounts Committee is instructed to submit proposals by December 1 .

The next question is to increase the financial independence of the regions.

Since 2020, the corporate income tax from SMEs has been transferred to local budgets. During this period, despite the decline in economic activity, revenues to local budgets were $25 \%$ higher than the plan. This indicates the increased interest of governors in the development of local business, an increase in investment and the tax base.

The trend in this direction must continue. I ask the Government to prepare a package of relevant proposals by the end of the year.

Kazakhstan is in line with a steady trend towards urbanization. Millions of cities should become the backbone of the global competitiveness of Kazakhstan, and regional centres - points of growth for the regions. Therefore, it will be necessary to develop a Law on the Development of Agglomerations and new standards for integrated urban development.

Adherence to the "people and infrastructure" principle is essential. The focus should be on the development of promising villages. The main goal is to ensure their compliance with the System of Regional Standards. These approaches should be enshrined in the Territorial Development Plan. 
27 monotowns now account for about $40 \%$ of industrial production. They are home to 1.4 million of our fellow citizens. We need substantiated decisions regarding the further functioning of monotowns. In the near future we will discuss this issue at a separate meeting.

Development of local self-government is an important priority. In the cities of central subordination and regional centres, a public participation budget has been successfully introduced. Dozens of improvement projects have been implemented in accordance with the real needs of citizens. This has been a successful experience. Now it is necessary to increase by 10 times the share of residents' participation in the budget for improvement and housing and communal services.

To strengthen the internal connectivity of the country, it is necessary to complete all the initiated projects on transport infrastructure. As part of the state programme Nurly Zhol, a single transport network is being formed connecting the centre with the regions. Strategically important infrastructure and social projects have been implemented. The task of the governors and the Government is to launch similar Infrastructure Development Programmes for each region.

On the ground, there are long-standing issues of infrastructure modernization.

The Government, together with the Samruk-Kazyna Fund, should start implementing the following large-scale projects: the construction of a combined cycle plant at the site of Almaty Combined Heat and Power plant-2, the modernization of Combined Heat and Power plant- 3 and the expansion of Combined Heat and Power plant-1, commissioning of $1000 \mathrm{MW}$ of new generating capacities in the southern region, and the reconstruction of cable networks in Almaty and the Almaty region. The total investment in these projects will amount to more than one trillion tenge (over USD 2.3 billion).

Together with strategic investors in various regions of the country, we will commission about 2,400 MW of renewable energy capacities.

Much attention should be paid to environmental problems in the country, especially air quality.

In the medium term, the 10 most polluted cities need to be supplied with gas and to switch to alternative energy sources. 
To improve the situation with gas supply to the western regions, implementation of three projects totalling 700 billion tenge (USD 1.6 billion) will begin this year. They include the construction of a gas processing plant at Kashagan, the construction of a looping line for the Makat-North Caucasus gas pipeline, and the modernization of the Beineu-Zhanaozen gas pipeline.

Now we come to the next important question. In the next ten years, the United Nations predicts a global water shortage. By 2030, the world's water shortage could reach $40 \%$. Therefore, we need to improve water conservation through the latest technology and digitalization. This is a strategic task there is no other way to prevent water shortages. The government needs to prepare specific solutions that will stimulate the introduction of water-saving technologies and effectively regulate water consumption.

To preserve the ecosystems of water bodies and the careful use of resources, we will begin the reconstruction of 120 canals. 9 new reservoirs will be built in Akmola, Almaty, West Kazakhstan, Zhambyl, Kyzylorda, Turkestan regions. We have all the necessary resources to implement this large-scale project.

To provide drinking water to the districts of the Atyrau and Mangistau regions, the Astrakhan-Mangyshlak main water pipeline will be modernised, and a new desalination plant will be built in the Kenderli village.

In general, the problem of access to drinking water has not been resolved, despite the fact that colossal funds have been allocated for this purpose for decades. Therefore, I set a task as part of the National Regional Development Project to provide $100 \%$ of cities and villages with clean drinking water within five years. This is a priority task for the Government.

There is one more question that I would like to touch upon separately. The world is moving towards greening industry and economy. Today these are no longer just words, but concrete decisions in the form of taxes, duties, and technical regulation measures. We cannot stand aside, as all this affects us directly through export, investment, and technology transfer. This is, without any exaggeration, the issue of sustainable development of Kazakhstan.

Therefore, I have set the goal of achieving carbon neutrality by 2060. It is necessary to work in this direction very pragmatically. The population and economy of our huge country are growing, and energy is needed for quality growth. 
With the gradual decline of the coal era, in addition to renewables, we will have to think about sources of reliable basic energy generation. By 2030, there will be a shortage of electricity in Kazakhstan.

Global experience suggests the most optimal solution - a peaceful atom. The question is not an easy one, therefore it is necessary to approach its solution as rationally as possible, without speculation and emotions. During the year, the Government and Samruk-Kazyna should explore the possibility of developing safe and environmentally friendly nuclear energy in Kazakhstan.

This issue must also be considered from the point of view of the development of engineering, the formation of a new generation of qualified nuclear engineers.

A promising area is also the production of „green” hydrogen and hydrogen energy in general. The government is instructed to prepare proposals on this issue as well.

\section{FORMATION OF AN EFFECTIVE ECOSYSTEM IN THE LABOUR MARKET}

The pandemic has brought about a significant transformation of the labour market, first and foremost the rapid development of the remote work format.

A new trend is gaining momentum amid the emergence of many new professions, automation, and digitalization of most processes. In such realities, personal competitiveness can only be ensured by repeated retraining and mastering of new professions. Therefore, a law "On professional qualifications" is needed. It should regulate the issues of recognition of qualifications, stimulate employees to improve their competencies.

Total digitalization has led to new forms of employment based on online platforms. Striking examples of this are taxi drivers, couriers, and others. This area needs government assistance in terms of social and health insurance, pensions, and taxation.

Migration processes also have a great influence on our labour market. Kazakhstan is the second country in the Commonwealth of Independent States in terms of the number of received labour migrants. We need the right solutions to problems in this area. The government will have to develop 
a new Migration Policy Concept. It should also reflect the mechanisms for protecting the rights of our citizens working abroad.

New approaches are also required to the issues of internal labour mobility. The Government will have to reformat the current mechanism for allocating benefits to citizens moving from the south to the north of the country. In particular, benefits can be provided not only through governors' offices, but also by reimbursing the costs of employers who independently hire workers from the southern regions.

It is necessary to actively help internal migrants who want to be engaged in independent business. It is also necessary to consider the possibility of providing them with land plots not only for the construction of houses, but also for agricultural activities, to provide wider access to government support measures.

I would like to touch upon on one more issue separately. Kazakhstan is a social state. Comprehensive assistance to citizens in difficult situations is one of our priorities. Unfortunately, paternalistic sentiments and social dependency are strengthening in society.

There are many citizens in the country who deliberately exploit state social programmes. This situation creates wrong attitudes in the public mind. As in any civilised country, they must answer before the law and society. At the same time, those who need real help remain outside the perimeter of support measures. Of course, the possibilities of our country are great, but they are not limitless.

The desire to receive unreasonable social benefits discourages a person from earning through their labour. This inappropriate lifestyle has already begun to negatively affect the value system of young people. Therefore, we need fundamental changes in the consciousness of citizens, society, and legislation. In the upcoming Social Code, all these issues need to be given close attention. 


\section{POLITICAL MODERNIZATIONAND PROTECTION OF HUMAN RIGHTS}

Phased political modernization is one of the main tasks of the strategic course of our state.

Over the past two years, we have managed to carry out a number of substantial transformations in this area. A new law has been adopted, which enshrined the principle of notifying of the plan to hold a rally; the threshold for political parties to enter the Mazhilis has been reduced to 5\% of votes received; and the option "against all" has been added to ballots.

These and other steps were widely supported by the society. They strengthen our vector for sustainable democratic development, qualitatively change the political system, and promote wider involvement of citizens in government.

But there is no room for complacency. Our goal is to further improve the efficiency of the state, transparency, and competitiveness of the political process. Therefore, political reforms will continue.

For the consistent strengthening of statehood, we will carry out all the transformations gradually, taking into account our specifics. This is the only true way to build a strong, just, and progressive state. Our citizens fully share this approach.

The most important step was the introduction of direct election of rural mayors. This is a fundamental moment of the political reform proposed by me in last year's Address. This decision directly affects the interests of the villagers, that is, more than $40 \%$ of Kazakhs. We are on the right track. And already in 2024, citizens will have the opportunity to elect district mayors in a pilot mode.

An important factor in the further modernization of local self-government is the development of civic culture.

The Presidential Administration will need to develop an effective mechanism to support civil initiatives in rural areas. It is necessary to adapt the system of grant financing to the requests of rural NGOs, to introduce a simplified procedure for their receipt. This will give a good impetus for social activity in the countryside. 
The introduction of a 30 percent quota for women and youth in the electoral lists encouraged the parties to work more actively, to rejuvenate their ranks, and to look for new faces. At the same time, the quota was not properly reflected in the final composition of the members of parliament. Therefore, in order to obtain a full-fledged effect, it is necessary to legislate the norm on the mandatory consideration of this quota when distributing mandates of members of parliament.

We are building an inclusive society. So far, in our country, people with special needs are poorly represented in social and political life. I propose to expand the list of quota categories of citizens. In addition to women and youth, a quota for people with special needs will be established.

As you know, I always highlight the field of human rights protection as a separate issue. Over the past two years, we have made significant progress in this direction.

In January of this year, I signed the Law on the Ratification of the Second Optional Protocol to the International Covenant on Civil and Political Rights, aimed at abolishing the death penalty. Now we have to harmonise the norms of the Criminal Code with the provisions of the Second Optional Protocol. I hope the corresponding law will be adopted by the end of the year.

At the beginning of the summer, in accordance with my decree, the Government approved the Comprehensive Plan for the Protection of Human Rights. This important document lays down a long-term institutional framework for further improvement of the human rights protection system in Kazakhstan.

After the adoption of the Comprehensive Plan, active work began on ensuring gender equality. In this regard, it is necessary to ensure maximum support for the economic and political positions of women in society. The Presidential Administration is responsible for this work.

Changes should also be made to the Concept of Family and Gender Policy.

Substantial changes are taking place in the law enforcement system. Administrative justice has been functioning since July 1, 2021. This institute is established a new type of a relationship between the state apparatus and citizens. Modern formats are being introduced to courts; redundant court procedures are being reduced. At the legislative level, the interpretation of 
all contradictions and ambiguities of the legislation is provided in favour of citizens and business.

With the introduction of the three-tier model, the protection of participants in criminal proceedings has increased. Since the beginning of this year, the unjustified involvement of more than 2,000 citizens in the law enforcement system has been prevented.

The efficiency of prosecutorial supervision has increased - $98 \%$ of baseless decisions were cancelled within three days. It is necessary to gradually expand the competence of prosecutors in the preparation of indictments. This will increase their responsibility and strengthen mechanisms for the legal assessment of the results of the investigation.

The internal affairs bodies are freed from a number of non-core functions. The status of district inspectors has been increased, and they are endowed with additional powers in the field of crime prevention.

In a number of regions, a police service model has been launched in a pilot mode. The next step is scaling it up. The success of this work largely depends on the involvement of local authorities, which must understand the essence of the reforms and provide assistance to the police.

At the same time, the practical issues of combating crime must not be overlooked. Just indignation of citizens is causing an increase in fraud. The Prosecutor General's Office will have to develop a set of measures to combat fraud and financial pyramids.

The prevention and suppression of sexual crimes against children, especially those left without parental care, should be under special control.

The spread of drugs, including synthetic drugs, poses a terrible threat to the well-being of future generations. Law enforcement agencies are instructed to create a powerful barrier against the spread of this infection among our citizens, especially among young people.

An effective fight against corruption should be continued. By the end of the year, the specialised agency needs to submit for approval a strategic document that defines the programme of our actions for the medium term. At the same time, special attention should be paid to the eradication of "everyday corruption". 
While defending the rights of citizens, we must not forget about the rights of human rights defenders, including lawyers. It is necessary to ensure the safety of their activities, to suppress illegal actions that impede their work.

All of the above measures are an integral part of our strategic course aimed at improving the political system and protecting human rights.

\section{CONSOLIDATION AS A MAIN FACTOR FOR FURTHER PROGRESS}

Kazakhstan is entering a completely new era, bringing fundamental changes in all spheres of life. In the context of global instability and a multitude of new challenges, we need to strengthen our values and form a clear image of the future.

Our main principle "unity in diversity" is unshakable. Therefore, the harmonious development of interethnic relations has always been and will be one of the main directions of the state policy of Kazakhstan. And this is not just rhetoric, this approach is supported by the absolute majority of Kazakhs. For our citizens, consent, tolerance is life itself, a living reality, conditioned by the linkages of cultures and languages.

We, according to the Constitution, are a single nation, and this is our unconditional strength. While supporting pluralism of opinions, we will at the same time strictly suppress any forms of radicalism, we will not allow encroachment on our state sovereignty and territorial integrity.

We must protect the unity and harmony in society as the apple of our eye. It is essential that all citizens realise the importance of harmonious interethnic and interfaith relations.

We have always been immune to disunity. And we will not tolerate any discrimination on the basis of language, nationality, or race, insulting and humiliating people, we will prosecute this according to the law. Such irresponsible steps, contrary to the Constitution, run counter to the interests of our country.

The development of the Kazakh language is one of the key priorities of state policy. We have achieved substantial results in this.

The Kazakh language is becoming the language of education and science, culture, and office work. It is consistently expanding the scope of 
its application. This is a natural phenomenon. Therefore, there is no reason to talk about the disadvantaged position of the Kazakh language.

In accordance with our Constitution, the state language is Kazakh. The Russian language has the status of an official language. Its use, according to our legislation, cannot be hindered.

Every citizen who connects his future with our country should make every effort to learn the state language. This is one of the manifestations of true patriotism.

The fact that our youth speaks different languages, including Russian, is an advantage for us.

The border between Kazakhstan and Russia is the longest in the world, and Russian is one of the six official languages of the United Nations. Therefore, this issue must be approached from the point of view of common sense.

We need to develop a culture of civilised dialogue and mutual respect. A large role in this is assigned to the Assembly of the People of Kazakhstan. Each of us should feel responsible for our Homeland, for all our citizens.

Effective use of the country's historical heritage and cultural potential is a crucial element in consolidating society and strengthening national identity. In this regard, Kazakhstan has ample opportunities, also for positioning itself advantageously in the international arena.

At the same time, our policy on this issue should be revised. Right now, for some reason, the state most often finances projects only of certain figures who are keen to absorb budgets.

Young and talented sculptors, painters, theatre actors, musicians, writers who master new genre formats and constantly experiment, while surviving at the expense of patrons of the arts, remain "underground". Yet Kazakh culture is gaining global traction thanks to them.

Therefore, by the end of the year, the Government, together with experts, need to present a plan of practical measures aimed at promoting a new culture and its talented representatives.

We should consider establishing a Creative Industry Support Fund.

The intelligentsia at all times played a special role in our country. They have always led our nation forward, guided the youth, fought against ignorance, and was engaged in enlightenment. These qualities are at the heart of our national code, and we must not lose it. 
This is the age of the Internet. A huge flow of negative information poisons the consciousness of the modern generation. False meanings and short-lived values are becoming widespread. This is a very dangerous trend.

At such moments, the active position of the intelligentsia is especially important. Its credibility is determined not by awards, but by real deeds.

The main task is to instil universal human values in young people. In our society, it is necessary to cultivate such qualities as patriotism, passion for knowledge, hard work, solidarity, and responsibility.

Therefore, I urge our intellectuals and creative people not to stay away from solving problems that affect the future of the country.

It is important for us to develop traditions of dialogue and civic participation, to cultivate progressive values that are deeply rooted in our internal solidarity and unity.

Only together can we strengthen our unique country identity. As the First President of Kazakhstan Nursultan Nazarbayev has repeatedly emphasized, interethnic and interfaith harmony is our invaluable asset.

For the sake of the future of our state, we are obliged to preserve and strengthen internal stability and national unity.

\section{Dear compatriots!}

These are the key priorities of our immediate agenda.

The main wealth of Kazakhstan is its people.

Ensuring the well-being of the people is a key goal of my work as President.

Therefore, today I would like to voice a number of additional initiatives aimed primarily at improving the welfare of Kazakh citizens.

\section{FIRST INITIATIVE}

I believe that there is a need to revise the minimum wage level. On the one hand, it is the most important macro indicator, on the other, it is an indicator clear to everyone.

The minimum wage has not increased since 2018. The global coronavirus crisis has increased the pressure on the incomes of the population. In addition, in terms of the minimum wage, Kazakhstan is inferior to a number 
of CIS countries. Therefore, I have decided to increase from January 1, 2022, the minimum wage from the current 42,500 tenge (USD 100) to 60,000 tenge (USD 140).

This measure will directly affect more than one million people, and indirectly - all the workers. It will reduce the "shadow" salary fund, the size of which today reaches $30 \%$ or maybe $40 \%$ of the declared.

An increase in the minimum wage will have a positive economic effect in the form of an increase in domestic consumption. This, according to experts, will lead to an increase in GDP by $1.5 \%$.

At the same time, it is necessary to move away from the inappropriate use of the minimum wage as an indicator in tax, social and other spheres.

I ask the Government and the Parliament to ensure that the necessary amendments to the legislation are made by the end of this year with entry into force next January.

\section{SECOND INITIATIVE}

More than 6.5 million people in Kazakhstan are hired workers. You know this well. The main source of income for them is wages.

At the same time, over the past ten years, the growth of the wage fund has lagged behind the growth of profit for business owners by almost $60 \%$. In this regard, the Government will develop "soft" measures to stimulate businesses to increase the wages of their employees.

Benefits through regulated procurement, as well as preferential access to government support, will be provided for employers who raise wages of employees.

\section{THIRD INITIATIVE}

The burden on the wage fund needs to be made clear and simple. Micro and small businesses are particularly affected by this. I propose to introduce a single payment from the wage fund with a reduction of the total burden from 34 percent to 25 percent. This will stimulate businesses to bring thousands of employees out of the shadows, who can become full-fledged participants in the pension, social and health insurance systems. 
Inconsistencies should not be allowed on this issue. Appropriate payment systems need to be prepared to avoid disruptions and business costs. The system should be operational starting January 1, 2023.

\section{FOURTH INITIATIVE}

Since 2020, the salaries of more than 600,000 public sector workers including teachers, doctors and social workers have been increased.

However, this measure did not affect other public sector workers, including employees of cultural institutions, archivists, librarians, technical workers, gamekeepers, drivers of vehicles in public companies, and others.

Therefore, from 2022 to 2025, the state will annually increase the salaries of these categories of public sector workers by $20 \%$ on average. This initiative will directly affect 600,000 of our citizens.

\section{FIFTH INITIATIVE}

The housing issue will always be one of the most important for people. Programmes such as "Baspana Hit" and "7-20-25" will end soon. At the same time, market mortgage rates are still high and are far from affordable for all Kazakhs. In this regard, a comprehensive housing programme will be developed. Its administrator will be the Otbasy Bank, which is being transformed into a national development institution. The bank is faced with the task of ensuring the accounting and distribution of housing among citizens on the basis of the "one window" principle.

I have already noted the positive effect of the initiative for the early use of pension savings. It also pushed people to demand payment from employers transparently. To maintain this trend, I consider it necessary to allow a transfer of a part of pension savings above the sufficiency threshold to an account with Otbasy Bank for the subsequent purchase of housing. This will also stimulate the habit of accumulating funds and managing them wisely.

\section{Dear members of parliament!}

During the first session, the Parliament of the VII convocation adopted 63 laws. 
As a result of the well-coordinated work of both Chambers, a legislative foundation was created for the implementation of the systemic transformations and reforms carried out in the country.

The regular session of the Parliament has started today. We have many important tasks before us. All legislations must undergo a high-quality and detailed study. You should always be persistent in upholding the interests of the people.

Each decision must be made, taking into account not only the needs of society, but also the capabilities of the state.

I wish you success in this responsible work!

\section{Dear compatriots!}

Our course is unshakable, the goal is clear.

We know what needs to be done to achieve it. We consistently transform our plans into reality, and we will complete all endeavours. We are ready for any challenges and difficulties.

As the Head of State, I will do my best for the good of the people.

Today, in order to solve the tasks that we are facing, it is necessary to consolidate the state and the entire society. Otherwise, tomorrow it might be too late.

Anyone who doubts the course of the Head of State, does not cope with the work, perhaps wants to somehow sit out, or evades the implementation of the President's instructions - it seems to me that they should leave their posts.

We are now entering a decisive stage in our development. The state apparatus is obliged to function as a single mechanism. Only in this case will we ensure the achievement of the set goals.

The cohesion of the nation is the main factor in the success of our country. When we are one, we are invincible.

It is not for nothing that the people say: "Where there is agreement, there is happiness."

Our strength lies in unity! Together we will work for the good of our country!

May our sacred Homeland be eternal! 